九州大学学術情報リポジトリ

Kyushu University Institutional Repository

\title{
Petrochemical Studies on the Active Volcanoes in Japan
}

Taneda, Sadakatu

Faculty of Science, Kyushu University

https://doi.org/10.5109/1526212

出版情報：九州大學理學部紀要：Series D, Geology. 12 (3)，pp.219-236，1962-06-11. Faculty of Science, Kyushu University バージョン：

権利関係 : 
Mem. Fac. Sci., Kyushu Univ., Ser. D, Geology, Vol. XII, No. 3,

pp. 219-236, text-figs. 12, June 11, 1962

\title{
Petrochemical Studies on the Active Volcanoes in Japan
}

\author{
By
}

\section{Sadakatu TANEDA}

\section{Contents}

\begin{tabular}{|c|c|c|}
\hline & Introduction. . . & \\
\hline & Acknowledgements & 219 \\
\hline I & Properties of lavas . . . . . . . . . . . . . . . & 220 \\
\hline II & $\begin{array}{l}\text { Comparison of the lavas of historic times and those of prehistoric } \\
\text { times in the average chemical composition . . . . . . . . . }\end{array}$ & \\
\hline III & Frequency distribution of lavas . . . . . . & 228 \\
\hline IV & $\begin{array}{l}\text { The variation trend of chemical composition of lavas throughout } \\
\text { historic times. . . . . . . . . . . . . . . . . }\end{array}$ & \\
\hline V & $\begin{array}{l}\text { Comparison of the lavas of historic times and those of prehistoric } \\
\text { times in the ratio Total } \mathrm{FeO}: \mathrm{MgO}: \mathrm{Alk} . . . . . . . . .\end{array}$ & \\
\hline & Consideration from the petro-volcanological standpoint & \\
\hline
\end{tabular}

\section{Introduction}

There are as many as 49 active volcanoes in Japan, with good results of chemical analyses of lavas, which are divided into 2 groups as follows:

group

I Volcanoes which have ejected lavas in historic times.

A few volcanoes which have ejected considerable amount of bombs or pumices, not accompanied with lava flow, in historic times are also treated.

II Volcanoes which have never ejected lava (flow) in historic times.

In this paper the general description on petrochemical properties of the lavas of historic times is given, with reference to the lavas of prehistoric times belonging to groups I and II.

Besides the stastic studies, the investigation of the various phenomena of an individual eruption as well as the properties of products is also significant. Standing such a viewpoint some considerations of the structure and eruption mechanism of the Sakura-zima volcano are given as an appendix.

\section{Acknowledgement}

I acknowledge the contribution made by many investigators and analysts, whose names are reluctantly not listed here (Refer to Table $1 \cdot 1-3$ ). 


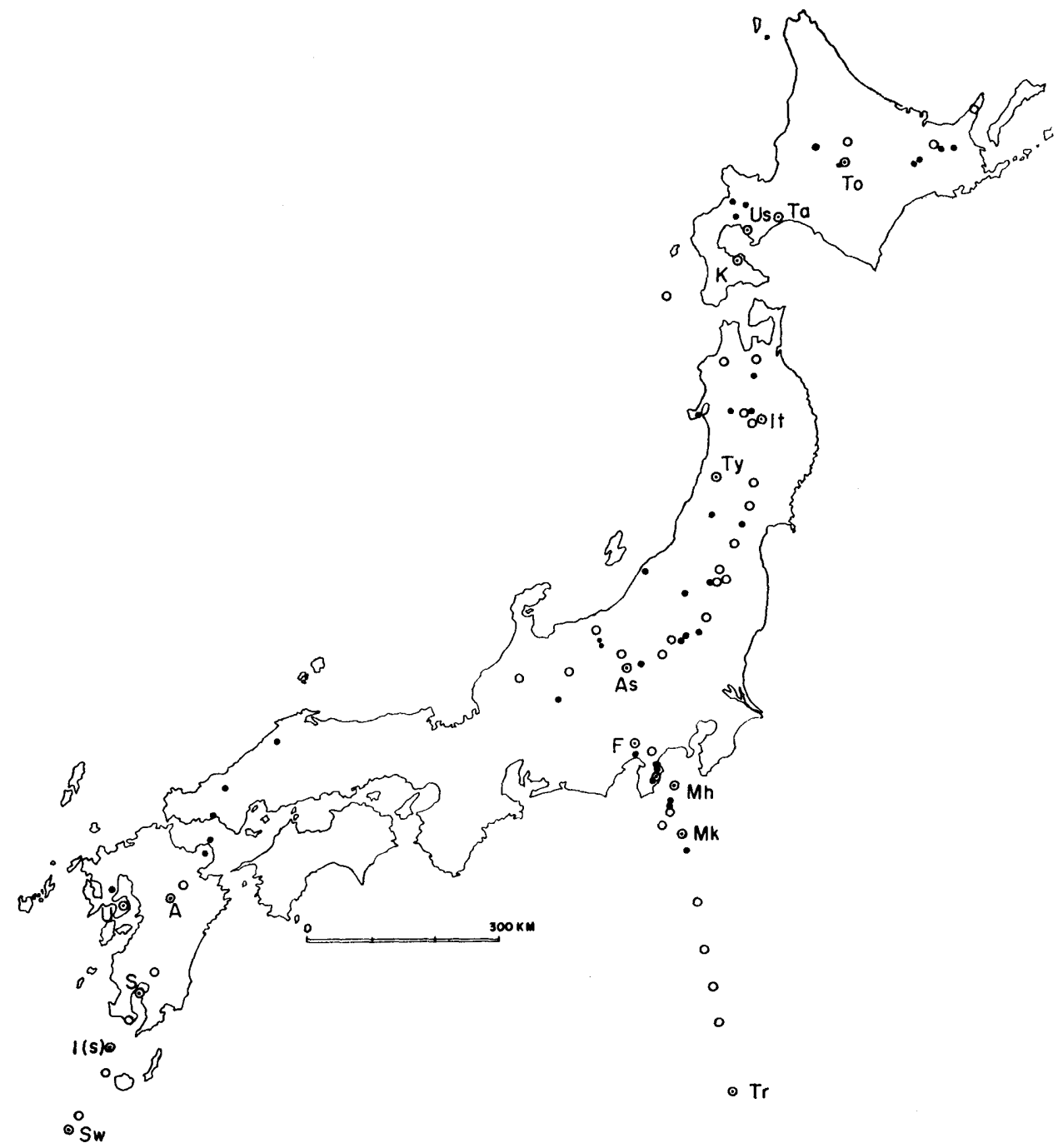

Fig. 1. Volcanoes with analytical data of lavas published before April 1961

Circles with dot in centre: Active volcanoes which have ejected lavas in historic times (group I).

Open circles: Active volcanoes which have apparently never flowed out lava in historic times (group II).

Solid circles : Volcanoes with no recorded eruptions.

This work has been made on the Grant in Aid for Scientific Researches from the Ministry of Education, Japan.

\section{Properties of lavas}

The properties of the lavas (lava flow and a few bombs or pumices produced by the distinctive eruptions) of historic times are listed in Table 1. 
Table 1-1. Lavas (lava, bomb, pumice) of historic times in Japan

\begin{tabular}{|c|c|c|c|c|c|c|c|c|c|c|c|}
\hline \multirow{3}{*}{ Name of volcano } & \multirow{3}{*}{$\begin{array}{l}\text { Year of } \\
\text { distinct } \\
\text { eruption }\end{array}$} & \multicolumn{9}{|c|}{ Properties of analysed lavas } & \multirow{3}{*}{$\begin{array}{c}\text { Number of } \\
\text { analyses } \\
\text { Remark }\end{array}$} \\
\hline & & \multirow{2}{*}{ Mode of occurrence } & \multirow{2}{*}{ Rock name* } & \multirow{2}{*}{$\mathrm{SiO}_{2}$} & \multirow{2}{*}{ Total FeO } & \multirow{2}{*}{$\mathrm{MgO}$} & \multirow{2}{*}{ Alkalies } & \multicolumn{3}{|c|}{ Norm } & \\
\hline & & & & & & & & Or & $\mathrm{Ab}$ & An & \\
\hline Tokati-dake & $1925-26$ & Mud flow bomb & Ao $2 p$ & 53.93 & 53.2 & 22.6 & 24.2 & 13 & 32 & 55 & \\
\hline \multirow{2}{*}{ Tarumai } & 1909 & Dome & A $2 p$ & 59.17 & 58.2 & 21.8 & 20.9 & 11 & 30 & 59 & 5 \\
\hline & 1909 & Bomb & A $2 p$ & 57.88 & 57.5 & 21.5 & 21.0 & 10 & 32 & 58 & 3 \\
\hline \multirow[t]{4}{*}{ Usu } & Pre 900 & Dome & $\mathrm{D}(\mathrm{a})$ hy & 71.25 & 44.6 & 7.7 & 47.6 & 13 & 64 & 34 & \\
\hline & $\begin{array}{l}1822(-) \\
1857\end{array}$ & $\begin{array}{l}\text { Dome } \\
\text { Mud flow fragm. }\end{array}$ & $\mathrm{D}(\mathrm{a})$ hy & 69.43 & 38.6 & 8.9 & 52.5 & 12 & 58 & 30 & 2 \\
\hline & $(1910$ & Ejecta & A $2 p$ & 52.40 & 54.4 & 19.5 & 25.9 & 16 & 39 & 45 & not essential?) \\
\hline & $1944-45$ & Dome & D hy a & 69.74 & 41.3 & 8.9 & 49.9 & 16 & 54 & 31 & \\
\hline \multirow{7}{*}{$\begin{array}{l}\text { Komaga-dake } \\
\text { Iwate } \\
\text { Tyōkai (Chokai) } \\
\text { Asama }\end{array}$} & $1928-29$ & $\begin{array}{l}\text { Pumice flow, bomb, } \\
\text { ejecta }\end{array}$ & A a hy & 60.43 & 50.2 & 17.9 & 32.0 & 9 & 54 & 37 & 8 \\
\hline & 1719 & Lava flow & $\mathrm{A}(\mathrm{o})$ a hy & 53.65 & 58.3 & 24.8 & 16.9 & 3 & 34 & 63 & \\
\hline & 1801 & Dome & A a hy & 60.62 & 44.3 & 19.1 & 36.6 & 20 & 45 & 35 & \\
\hline & 1783 & Lava flow & $\mathrm{A}(\mathrm{o})$ hy a & 61.38 & 43.2 & 25.5 & 31.3 & 13 & 44 & 44 & 2 \\
\hline & & Ejecta & $A(0)$ hy a & 61.52 & 43.3 & 24.4 & 32.3 & 13 & 49 & 38 & 2 \\
\hline & $(1930$ & Bomb & A & 59.67 & & & & & & & Alk. : n.d.) \\
\hline & $\begin{array}{l}1929 \text { (and } \\
1927-32)\end{array}$ & Bomb & $\mathrm{A}(0)$ hy a & 60.03 & 45.6 & 26.4 & 28.0 & 10 & 41 & 49 & 2 \\
\hline \multirow[t]{3}{*}{ Huzi (Fuji) } & 864 & Lava flow & B $(2 p) \circ$ & 51.30 & 55.3 & 26.6 & 18.0 & 7 & 34 & 59 & \\
\hline & 1707 & Scoria & $\mathrm{Ba} \circ$ & 50.95 & 55.9 & 26.2 & 17.9 & 7 & 38 & 54 & 2 \\
\hline & 1707 & Ejecta & $\mathrm{Aa}$ & 65.81 & 41.1 & 11.8 & 47.1 & 24 & 49 & 27 & 4 \\
\hline
\end{tabular}

* B-Basalt A-Andesite D-Dacite A(o)hy a-Olivine-bearing hypersthene-augite andesite p-pyroxene

Tada, H. \& Tsuya H. (1927): Bull. Earthq. R. I., 2; Suzuki, J. (1935): Bull. Volc. S. J., 2 ; Katsui, Y. \& Takahasi, T. (1960): Jour. Jap. As. P.M.E'G., 44; Ishikawa, T. (1952): Jour. Fac. Sc. Hokkaido Univ., IV, 7; Katsui, Y. (1959): Bull. Geol. Com. Hokkaido, No. 38; Sato, D. (1913); Geol. Surv.; Yagi, K. (1953): Trans. Am. Geoph. Un., 34; Sedo, K. (1931): Jour. Jap. As. P.M.E'G., 6; Sedo, K. \& Yagi, T. (1931): Jour. Jap. As. P.M.E'G., 5; Tsuya, H. (1929): Bull. Earthq. R.I., 7; Kawano, Y. \& Aoki, K. (1959): Sc. Rep. Tohoku Univ., III, 4 ; Önuma, k. (1954): oral com., Katsui, Y. (1954): Jour. Geol. S.J. 60 ; Kozu, S. (1932): Bull. Volc. S.J., 1; Tsuya, H. (1933): Geog., 2 \& Bull. Earthq. R.I., 11; Iwasaki, I. (1935): Jour. Chem. S.J., 56, (1936): Do., 57; Tsuya, H. (1937); Bull. Earthq. R.I., 15; 
Table 1-2

\begin{tabular}{|c|c|c|c|c|c|c|c|c|c|c|c|}
\hline \multirow{3}{*}{ Name of volcano } & \multirow{3}{*}{$\begin{array}{l}\text { Year of } \\
\text { distinct } \\
\text { eruption }\end{array}$} & \multicolumn{9}{|c|}{ Properties of analysed lavas } & \multirow{3}{*}{$\begin{array}{c}\text { Number of } \\
\text { analyses ; } \\
\text { Remark }\end{array}$} \\
\hline & & \multirow{2}{*}{ Mode of occurrence } & \multirow{2}{*}{ Rock name* } & \multirow{2}{*}{$\mathrm{SiO}_{2}$} & \multirow{2}{*}{ Total $\mathrm{FeO}$} & \multirow{2}{*}{$\mathrm{MgO}$} & \multirow{2}{*}{ Alkalies } & \multicolumn{3}{|c|}{ Norm } & \\
\hline & & & & & & & & Or & $\mathrm{Ab}$ & An & \\
\hline \multirow{7}{*}{$\begin{array}{l}\text { Mihara-yama } \\
\text { (O-sima) }\end{array}$} & $1330 \pm$ & Lava flow & $\mathrm{B}$ & 52.5 & 64.6 & 24.1 & 11.3 & 5 & 36 & 59 & 9 \\
\hline & $1421 ?$ & Lava flow & B & 52.2 & 63.9 & 24.7 & 11.2 & 5 & 34 & 61 & 7 \\
\hline & $1552 ?$ & Lava flow & $\mathrm{B}(0)$ & 52.3 & 64.7 & 23.7 & 11.4 & 5 & 34 & 61 & 3 \\
\hline & 1684 & Lava flow & B & 52.2 & 64.8 & 23.6 & 11.4 & 5 & 35 & 60 & 5 \\
\hline & 1778 & Lava flow & $B$ & 51.7 & 65.3 & 23.3 & 11.2 & 5 & 35 & 61 & 5 \\
\hline & 1912 & Lava flow & B hy & 51.67 & 66.6 & 24.1 & 9.3 & 4 & 22 & 73 & 5 \\
\hline & $1950-51$ & Lava flow & B hy a & 52.45 & 66.4 & 23.5 & 10.1 & 4 & 28 & 68 & \\
\hline \multirow[t]{3}{*}{ Miyake-zima } & $\begin{array}{l}1643 ? \\
(1712\end{array}$ & $\begin{array}{l}\text { Lava flow } \\
\text { Lava flow) }\end{array}$ & $B$ & 51.80 & $6 \overline{0.4}$ & 21.1 & 13.5 & 5 & 41 & 55 & Aphiric \\
\hline & 1874 & Lava flow & Ao(hy) a & 53.46 & 65.3 & 18.6 & 16.1 & 8 & 38 & 55 & 4 \\
\hline & 1940 & Lava flow, Lapilli & Bo & 52.57 & 62.1 & 23.2 & 14.6 & 6 & 37 & 58 & Lapilli \\
\hline \multirow[t]{5}{*}{ Myozin-syo } & 1952 & $\begin{array}{l}\text { Pumice with gray } \\
\text { patch }\end{array}$ & D hy a & 68.23 & 42.2 & 14.2 & 43.6 & 8 & 60 & 33 & White part \\
\hline & 1952 & Gray patch & D 2p q & 63.30 & 52.7 & 22.0 & 27.3 & 5 & 42 & 52 & \\
\hline & 1952 & Pumice & D 2p q & 65.39 & 45.9 & 13.8 & 40.3 & 6 & 56 & 38 & White \\
\hline & (1953 & Ash & & 63.57 & 46.3 & 20.6 & 33.1 & 8 & 52 & 40) & \\
\hline & 1960 & Pumice with & $\mathrm{D} 2 \mathrm{p}$ & 68.49 & 34.6 & 13.7 & 51.6 & 9 & 58 & 33 & \\
\hline \multirow{2}{*}{ Tori-sima(Tonan) } & 1960 & Dark stripe & A & 57.82 & 53.5 & 23.0 & 23.5 & 6 & 43 & 50 & \\
\hline & 1939 & Lava flow & BA a hy & 54.51 & 60.3 & 22.7 & 16.9 & 3 & 41 & 57 & \\
\hline
\end{tabular}

Tsuboi, S. (1917): Jour. Geol. S.J., 24, (1918); Do., 25; Tsuya, H. \& Morimoto, R. (1951): Bull. Earthq. R.I., 30; Kuno, H. (1958): Bull. Volc. S.J., 3; Katsura, T. \& Nakamura, K. (1960): Bull. Volc. S.J., 5; Isshiki, N. (1960): Expl. Text Geol. Map (Miyake-zima); Morimoto, R. (1957): CGI, xx., (1960): Assembly Volc. S.J., Tanakadate, H. (1940): Jour. Geol. S.J., 47; Tsuya, H. (1937): Bull. Earthq. R.I., 15

Table 1-1 3 Abbr. R.I. Research Institute, S.J. Society of Japan

P.M.E'G. Petrologist, Mineralogist and Economic Geologist * refer to Table 1-1 
Table 1-3

\begin{tabular}{|c|c|c|c|c|c|c|c|c|c|c|c|}
\hline \multirow{3}{*}{ Name of volcano } & \multirow{3}{*}{$\begin{array}{l}\text { Year of } \\
\text { distinct } \\
\text { eruption }\end{array}$} & \multicolumn{9}{|c|}{ Properties of analysed lavas } & \multirow{3}{*}{$\begin{array}{c}\text { Number of } \\
\text { analyses; } \\
\text { Remark }\end{array}$} \\
\hline & & \multirow{2}{*}{ Mode of occurrence } & \multirow{2}{*}{ Rock name } & \multirow{2}{*}{$\mathrm{SiO}_{2}$} & \multirow{2}{*}{ Tatal $\mathrm{FeO}$} & \multirow{2}{*}{$\mathrm{MgO}$} & \multirow{2}{*}{ Alkalies } & \multicolumn{3}{|c|}{ Norm } & \\
\hline & & & & & & & & Or & $\mathrm{Ab}$ & An & \\
\hline \multirow{4}{*}{$\begin{array}{l}\text { Iwo-zima } \\
\text { (Volc. Is.) } \\
\text { Aso }\end{array}$} & 1914 & Pumice & TA $\circ \mathrm{p}$ & 60.82 & 27.9 & 11.1 & 61.0 & 31 & 60 & 9 & \\
\hline & 1929 & Ejecta & $A \circ 2 p$ & 53.52 & 49.5 & 22.5 & 27.9 & 16 & 39 & 45 & \\
\hline & 1933 & Bomb & $A \circ 2 p$ & 52.66 & 46.8 & 23.4 & 29.9 & 16 & 45 & 39 & \\
\hline & 1958 & Scoria block & A hy a & 53.50 & 49.7 & 21.3 & 29.0 & 15 & 47 & 38 & 2 \\
\hline \multirow{2}{*}{ Unzen } & $1657-63$ & Lava flow & $\mathrm{A} \circ \mathrm{b} \mathrm{h}$ & 57.11 & 43.9 & 26.1 & 30.0 & 16 & 38 & 46 & 3 \\
\hline & 1792 & Lava flow & $\mathrm{A} \mathrm{b} \mathrm{h}$ & 65.37 & 33.2 & 17.2 & 49.7 & 19 & 48 & 32 & 3 \\
\hline \multirow{7}{*}{ Sakura-zima } & $1471-76$ & Lava flow & A $2 p$ & 66.35 & 43.1 & 11.6 & $4 \overline{5} .4$ & 16 & 50 & 34 & 4 \\
\hline & 1779 & Lava flow & A $2 p$ & 64.13 & 46.1 & 13.6 & 40.1 & 16 & 51 & 33 & 4 \\
\hline & 1914 & Lava flow & A $2 p$ & 61.04 & 46.7 & 18.3 & 34.8 & 14 & 44 & 42 & 3 \\
\hline & 1914 & Lava flow & A $2 p$ & 59.01 & 47.0 & 24.0 & 28.8 & 14 & 37 & 48 & 2 \\
\hline & 1939 & Bomb & $A \circ 2 p$ & 57.11 & 48.4 & 24.1 & 27.6 & 13 & 42 & 46 & 4 \\
\hline & 1946 & Lava flow & A $2 p$ & 61.25 & 50.7 & 19.3 & 30.0 & 15 & 38 & 47 & 2 \\
\hline & $1956-$ & Bomb & A $2 p$ & 59.69 & 49.0 & 17.9 & 33.1 & 13 & 44 & 44 & \\
\hline \multirow{2}{*}{$\begin{array}{l}\text { Iwo-zima } \\
\quad \text { (Satunan) }\end{array}$} & 1934 & Lava flow & A a hy & 64.51 & 39.6 & 19.0 & 41.4 & $1 \overline{5}$ & 46 & 39 & 3 \\
\hline & 1934 & Pumice, Bomb & A $2 p$ & 69.72 & 42.5 & 13.3 & 44.2 & 16 & 52 & 32 & 2 \\
\hline \multirow[t]{3}{*}{ Suwanose-zima } & 1813 & Lava flow & $\mathrm{A}$ & 60.01 & 46.2 & 18.4 & $3 \bar{\jmath} .4$ & 16 & 45 & 40 & \\
\hline & 1884-89? & Lava flow & $\mathrm{A}$ & 59.97 & 47.7 & 17.9 & 34.4 & 15 & 44 & 41 & \\
\hline & $1952 ?$ & Bomb & $\mathrm{A}$ & 57.83 & 50.3 & 18.4 & 31.3 & 15 & 45 & 41 & 2 \\
\hline
\end{tabular}

Tsuya, H. (1936): Bull. Eatrhq. R.I., 14; Iwasaki, I. (1937): Jour. Chem. S.J., 63; Kawano, Y. (1933): Jour. Jap. As. P.M.E'G., 12; Homma, H. \& Mukae, M. (1938); Bull. Volc. S.J., 4; Matsumoto, H. (1958): Jour. Jap. As. P.M.E'G., 43; Taneda, S. (Aso, unpublished); Homma, H. (1936): Bull. Volc. S.J., 3; Kurasawa, H. \& Takahasi, K. (1959): Assembly Geol. S.J.; Yamamoto, T. (1960): Bull. Volc. S.J., 5; Yamaguchi, K. (Taneda, S. 1952: Guide Book-Sakura-jima, Kyushu Univ.); Morimoto, R. (1948): Bull. Earthq. R.I., 26; Taneda, S. \& Morita, J. (1958): Jour. Jap. As. P.M.E'G., 42; Tanakadate, H. (1935): Proc. Imp. Ac. Tokyo, 11; Matsumoto, H. (1954): Kumamoto J.S., BI, 1, (1956); Do., 2; Abbr. b-biotite, h-hornblende, T-trachytic,

* refer. to Table 1-1 
Table. 2-1. Average (except column V) chemical compositions of lavas (including few bombs \& pumices) of historic times in Japan

\begin{tabular}{|c|c|c|c|c|c|}
\hline No. of anal. & $\begin{array}{l}I \\
20\end{array}$ & $\Pi_{10}$ & $\begin{array}{l}\text { III } \\
12\end{array}$ & $\begin{array}{r}\text { IV } \\
9\end{array}$ & $\begin{array}{l}\mathrm{V} \\
1\end{array}$ \\
\hline $\mathrm{SiO}_{2}$ & 52.56 & 58.53 & 61.73 & 67.61 & 71.25 \\
\hline $\mathrm{TiO}_{2}$ & 1.18 & 0.72 & 0.65 & 0.57 & 0.43 \\
\hline $\mathrm{Al}_{2} \mathrm{O}_{3}$ & 16.47 & 17.17 & 16.18 & 15.23 & 13.21 \\
\hline $\mathrm{Fe}_{2} \mathrm{O}_{3}$ & 3.30 & 2.41 & 2.20 & 1.62 & 3.19 \\
\hline $\mathrm{FeO}$ & 8.50 & 5.38 & 4.32 & 2.88 & 1.96 \\
\hline $\mathrm{MnO}$ & 0.20 & 0.27 & 0.15 & 0.11 & 0.27 \\
\hline $\mathrm{MgO}$ & 4.44 & 3.19 & 2.75 & 1.36 & 0.84 \\
\hline $\mathrm{CaO}$ & 9.65 & 7.66 & 6.11 & 4.36 & 3.10 \\
\hline $\mathrm{Na}_{2} \mathrm{O}$ & 2.40 & 2.87 & 3.49 & 3.68 & 4.02 \\
\hline $\mathrm{K}_{2} \mathrm{O}$ & 0.77 & 1.31 & 1.55 & 1.38 & 1.15 \\
\hline $\mathrm{H}_{2} \mathrm{O}+$ & 0.29 & 0.52 & 0.51 & 0.60 & 0.50 \\
\hline $\mathrm{H}_{2} \mathrm{O}-$ & 0.29 & 0.24 & 0.21 & 0.27 & 0.20 \\
\hline $\mathrm{P}_{2} \mathrm{O}_{5}$ & 0.18 & 0.19 & 0.18 & 0.18 & 0.46 \\
\hline Total & 100.22 & 100.46 & 100.03 & 99.85 & 100.63 \\
\hline$\frac{\mathrm{Al}_{2} \mathrm{O}_{3}}{\mathrm{CaO}}$ & 1.70 & 2.24 & 2.65 & 3.49 & 3.49 \\
\hline $\begin{array}{r}\mathrm{Na}_{2} \mathrm{O} \\
\mathrm{K}_{2} \mathrm{O}\end{array}$ & 3.11 & 2.19 & 2.25 & 2.66 & 4.25 \\
\hline$\frac{\text { Total FeO }}{\mathrm{MgO}}$ & 2.62 & 2.44 & 2.36 & 3.26 & 11.10 \\
\hline$\frac{\mathrm{Al}_{2} \mathrm{O}_{3}}{\mathrm{Na}_{2} \mathrm{O}+\mathrm{K}_{2} \mathrm{O}}$ & 3.19 & 4.10 & 3.21 & 3.00 & 2.55 \\
\hline$\frac{\mathrm{Fe}_{2} \mathrm{O}_{3}}{\mathrm{FeO}}$ & 0.38 & 0.44 & 0.46 & 0.56 & 0.31 \\
\hline Total $\mathrm{FeO}$ & 60.1 & 50.6 & 44.67 & 40.3 & 44.6 \\
\hline $\mathrm{MgO}$ & 23.3 & 21.4 & 19.5 & 12.7 & 7.7 \\
\hline $\mathrm{Na}_{2} \mathrm{O}+\mathrm{K}_{2} \mathrm{O}$ & 16.6 & 28.0 & 35.8 & 47.1 & 47.6 \\
\hline
\end{tabular}

I $50 \leqq \mathrm{SiO}_{2}<55$, II $55 \leqq \mathrm{SiO}_{2}<60$, III $60 \leqq \mathrm{SiO}_{2}<65$, IV $65 \leqq \mathrm{SiO}_{2}<70$

\section{Conparison of the lavas of historic times and those of prehistoric times in the average chemical composition}

The average chemical composition of the lavas of historic times (Table 2.1), compared with those of prehistoric times (Table 2.2) are characterized by low $\mathrm{K}_{2} \mathrm{O}$, $\mathrm{H}_{2} \mathrm{O}(+)$, and $\mathrm{Fe}_{2} \mathrm{O}_{3} / \mathrm{FeO}$, and high $\mathrm{FeO}$ (Total) (distinct at $\mathrm{SiO}_{2}<60,>70$ ), $\mathrm{MnO}$ (distinct between $\mathrm{SiO}_{2} 50$ and 60 ), $\mathrm{Na}_{2} \mathrm{O} / \mathrm{K}_{2} \mathrm{O}\left(\mathrm{SiO}_{2}>55\right), \mathrm{Al}_{2} \mathrm{O}_{3} / \mathrm{Na} 2 \mathrm{O}+\mathrm{K}_{2} \mathrm{O} \quad\left(\mathrm{SiO}_{2}<60\right.$, 
Table 2-2. Average chemical compositions of lavas (lava, bomb, pumice) of prehistoric times of Japanese active volcanoes which have ejected lavas in historic times

\begin{tabular}{|c|c|c|c|c|c|c|}
\hline No. of anal. & $\stackrel{I}{7}$ & $\begin{array}{l}\text { II } \\
25\end{array}$ & $\frac{\text { III }}{19}$ & $\begin{array}{l}\text { IV } \\
20\end{array}$ & $\begin{array}{l}\mathrm{V} \\
6\end{array}$ & $\begin{array}{l}\text { VI } \\
3\end{array}$ \\
\hline $\mathrm{SiO}_{2}$ & 49.21 & 52.23 & 58.11 & 61.40 & 66.11 & 71.71 \\
\hline $\mathrm{TiO}_{2}$ & 1.02 & 1.07 & 0.70 & 0.72 & 0.59 & 0.54 \\
\hline $\mathrm{Al}_{2} \mathrm{O}_{3}$ & 17.89 & 17.59 & 17.00 & 16.61 & 15.24 & 14.15 \\
\hline $\mathrm{Fe}_{2} \mathrm{O}_{3}$ & 3.84 & 3.42 & 3.00 & 2.98 & 1.87 & 0.93 \\
\hline $\mathrm{MnO}$ & 0.18 & 0.20 & 0.19 & 0.13 & 0.09 & 0.11 \\
\hline $\mathrm{MgO}$ & 5.29 & 4.40 & 3.36 & 2.76 & 1.40 & 0.29 \\
\hline $\mathrm{CaO}$ & 10.62 & 9.53 & 7.03 & 5.96 & 4.43 & 2.18 \\
\hline $\mathrm{Na}_{2} \mathrm{O}$ & 2.06 & 2.61 & 3.10 & 3.11 & 3.66 & 4.25 \\
\hline $\mathrm{K}_{2} \mathrm{O}$ & 0.60 & 0.72 & 1.46 & 1.81 & 2.11 & 3.13 \\
\hline $\mathrm{H}_{2} \mathrm{O}+$ & 0.50 & 0.49 & 0.64 & 0.71 & 0.63 & 0.87 \\
\hline $\mathrm{H}_{2} \mathrm{O}-$ & 0.24 & 0.26 & 0.40 & 0.51 & 0.54 & 0.40 \\
\hline $\mathrm{P}_{2} \mathrm{O}_{5}$ & 0.17 & 0.18 & 0.20 & 0.17 & 0.21 & 0.07 \\
\hline Total & 99.90 & 100.18 & 100.14 & 100.27 & 100.24 & 100.01 \\
\hline$\frac{\mathrm{Al}_{2} \mathrm{O}_{3}}{\mathrm{CaO}}$ & 1.68 & 1.84 & 2.41 & 2.78 & 3.44 & 6.49 \\
\hline$\frac{\mathrm{Na}_{2} \mathrm{O}}{\mathrm{K}_{2} \mathrm{O}}$ & 3.43 & 3.62 & 2.12 & 1.71 & 1.73 & 1.35 \\
\hline$\frac{\text { Total } \mathrm{FeO}}{\mathrm{MgO}}$ & 2.25 & 2.42 & 2.32 & 2.28 & 3.66 & 8.34 \\
\hline$\frac{\mathrm{Al}_{2} \mathrm{O}_{3}}{\mathrm{Na} \mathrm{a}_{2}+\mathrm{K}_{2} \mathrm{O}}$ & 6.72 & 5.28 & 3.72 & 3.37 & 2.64 & 1.91 \\
\hline $\begin{array}{c}\mathrm{Fe}_{2} \mathrm{O}_{3} \\
\mathrm{FeO}\end{array}$ & 0.46 & 0.46 & 0.60 & 0.85 & 0.55 & 0.67 \\
\hline Total $\mathrm{FeO}$ & 59.5 & 57.5 & 49.1 & 44.6 & 41.3 & 23.2 \\
\hline $\mathrm{MgO}$ & 26.9 & 24.2 & 21.6 & 19.9 & 11.5 & 2.9 \\
\hline $\mathrm{Na}_{2} \mathrm{O}+\mathrm{K}_{2} \mathrm{O}$ & 13.5 & 18.3 & 29.3 & 35.5 & 47.3 & 73.9 \\
\hline
\end{tabular}

I $\mathrm{SiO}_{2}<50 \%$, II $50 \leqq \mathrm{SiO}_{2}<55$, III $55 \leqq \mathrm{SiO}_{2}<60, \quad$ IV $60 \leqq \mathrm{SiO}_{2}<65, \quad$ V $65 \leqq \mathrm{SiO}_{2}<70$ VI $70 \leqq \mathrm{SiO}_{2}<75$

$>65)$ and Total $\mathrm{FeO} / \mathrm{MgO}\left(\mathrm{SiO}_{2}<65,>70\right){ }^{*}$

The alkali-lime index is 64.4 for all lavas of historic times of Japanese active volcanoes, while it is 63.6 for lavas of prehistoric times of the same volcanoes. On the other hand it is noticed that in general the index Krereases towards the inner side (the Japan Sea coast) of the Japan Islands (Taneda, 1951; Ishikawa \& Katsui,

* If all of the specimens for analyses are fresh compretely, the differences in the values of $\mathrm{H}_{2} \mathrm{O}$ and $\mathrm{Fe}_{2} \mathrm{O}_{3} / \mathrm{FeO}$ are significant for the studies of volcanism. 
Table 3. Classificaton of lavas (and bomb and pumice) of historic and prehistoric times according

to the silica quantities and localities

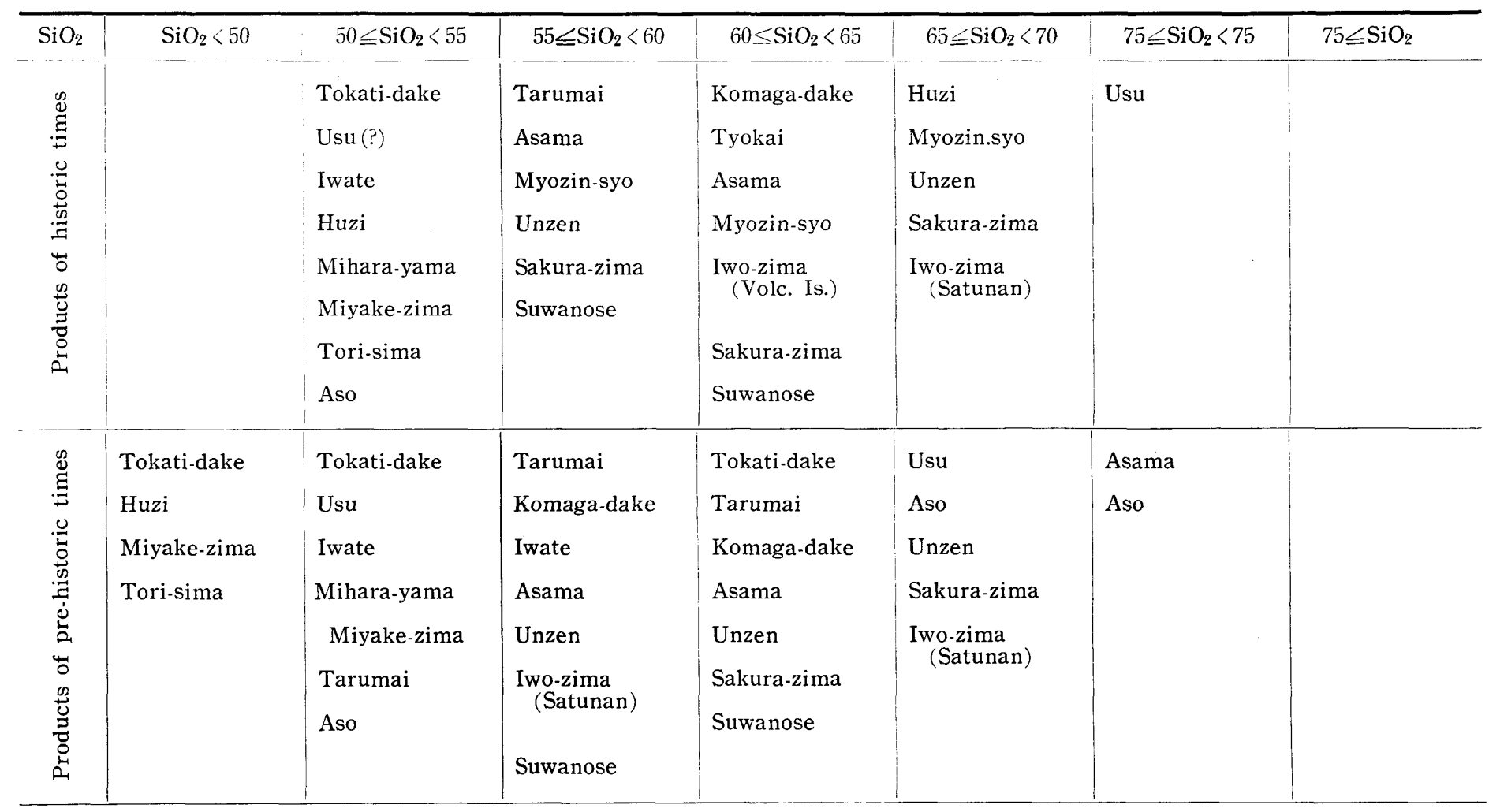


1959).

Consequently the characteristics of the lavas of historic times are referred largely to the geographical distribution of active volcanoes in this region.

\section{Frequency distribution}

a. Frequency distribution of lavas based on the silica percentage

The curve of frequency distribution of lavas of historic times based on the silica percentage is as shown in Fig. 2 characterized by two peaks, one (the highest peak) between 52 and 53 and two (a lower peak) between 59 and 61 in the silica percentage. The former is caused by the products of the Mihara-yama (Ô-sima), Miyake-zima,

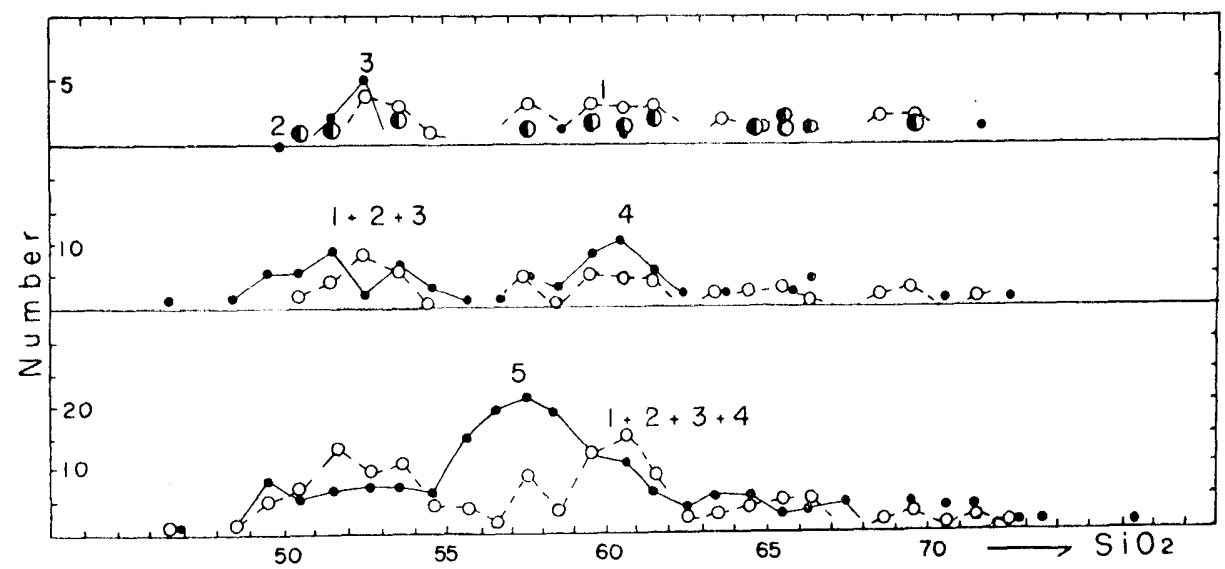

Fig. 2. Frequency distribution diagram for the lavas of Japanese active volcanoes.

1: Lavas produced by the eruptions since 1900

2: Lavas produced by the eruptions between 1700-1900 Lavas of historic

3: Lavas produced by the eruptions prior to 1700 times

4: Lavas of prehistoric times of the volcanoes which have ejected lavas in historic times.

5: Lavas of the volcanoes which exploded but never flowed out lava in historic times.
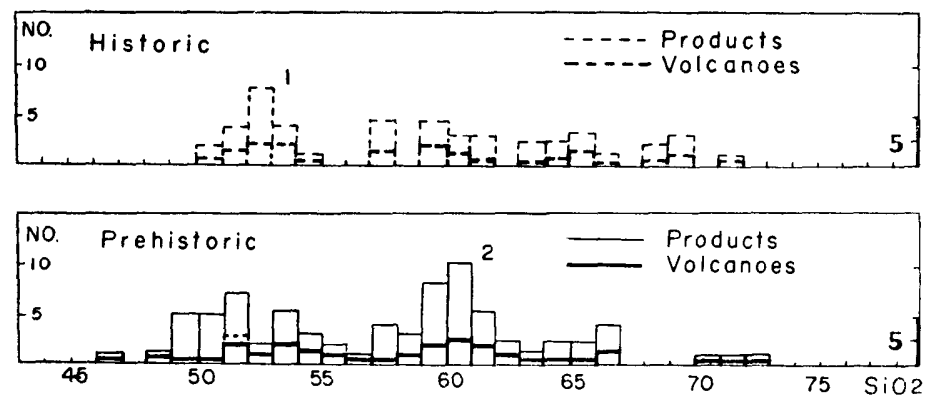

Fig. 2.b. Frequency distribution of active volcanoes which have ejected lavas in historic times and that of their essential products (lavas).

The Frequency distribution of volcanoes are based on the silica percentages of their products. 
Aso and Usu (?) volcanoes, and the latter is caused by those of the Asama, Sakura-zima, Komaga-dake (Hokkaido), Tarumai, Iwo-zima (Volcano Islands) and Swanose-zima volcanoes (Table 3 and Fig. 2b).

The curve for the lavas of prehistoric times has the highest peak between 60 and 61 , and the second peak between 51 and 52. The former is caused by the products of the Tokati-dake, Tarumai, Unzen, Sakura-zima and Suwanose-zima volcanoes, and the latter is caused by those of the Mihara-yama, Huzi, and Miyakezima volcanoes (Table 3 and Fig. $2 \mathrm{~b}$ ). In Fig. $2 \mathrm{~b}$ it is noticed that the frequency peaks for products are well corresponding to the peaks for volcanoes.

It should be significant that the frequency distribution curve for the lavas of Japanese active volcanoes shows two peaks, and that the frequency peaks for lavas
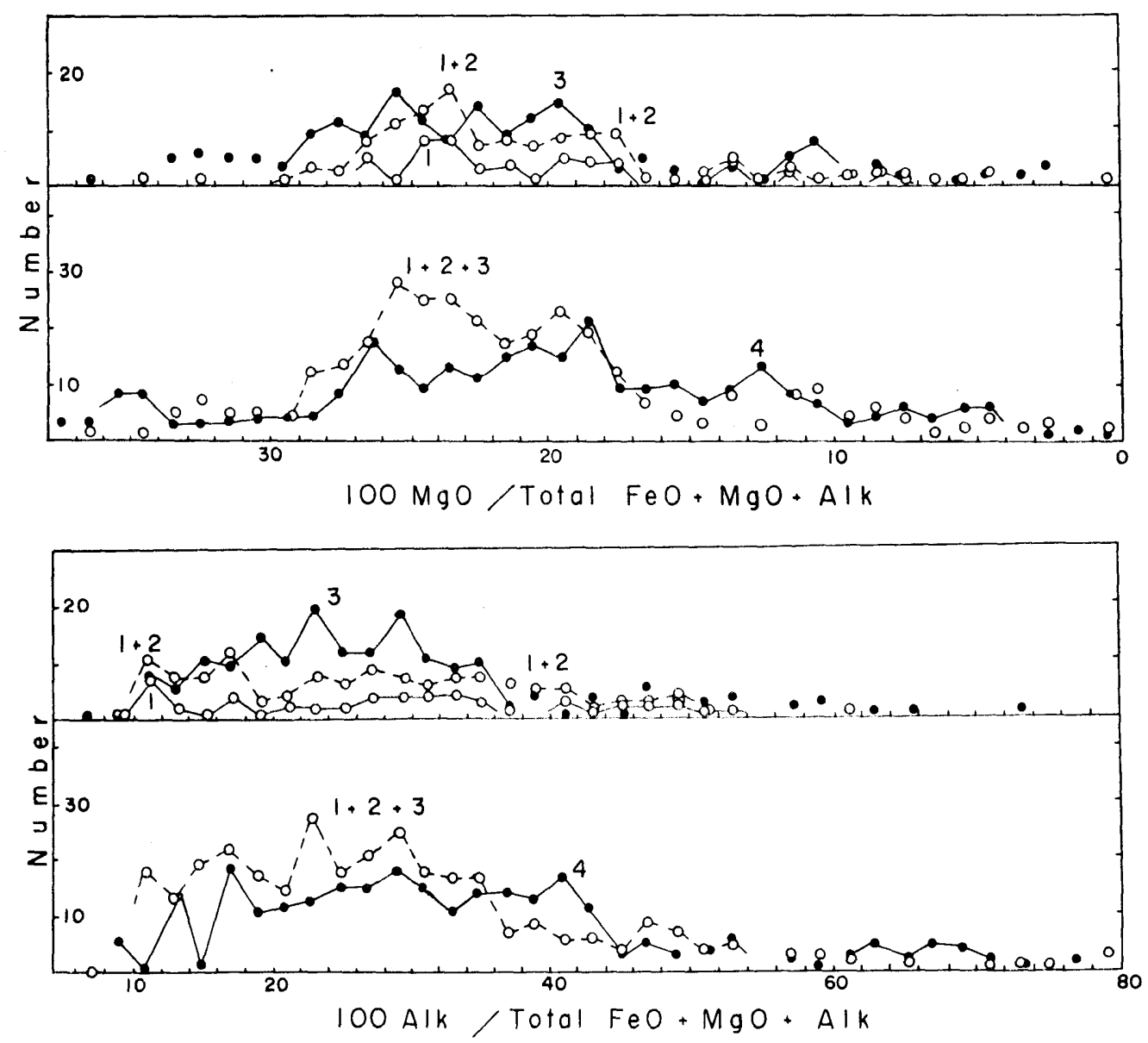

Fig. 3. Frequency distribution diagram for the lavas of Japanese active volcanoes.

1: Lavas of historic times.

2: Lavas of prehistoric times of the volcanoes which have ejected lavas in historic times.

3: Lavas of the volcanoes which exploded but never flowed out lava in historic times. 
are well corresponding to the peaks for volcanoes.

b. Frequency distribution of lavas based on the $\mathrm{Alk} / \mathrm{Total} \mathrm{FeO}+\mathrm{MgO}+\mathrm{Alk}$ ratio The ratio $\mathrm{MgO}:($ Total $\mathrm{FeO}+\mathrm{MgO}+\mathrm{Alk}$ ) of all analytical results were calculated. The curves for frequency distribution are shown in Fig. 3.

c. Frequency distribution of lavas based on the $\mathrm{MgO} / \mathrm{Total} \mathrm{FeO}+\mathrm{MgO}+\mathrm{Alk}$ ratio The curves for frequency distribution are shown in Fig. 3.

\section{d. Remarks}

It is noticed that the frequency curves based on $100 \mathrm{Alk} / \mathrm{Total} \mathrm{FeO}+\mathrm{MgO}+\mathrm{Alk}$ show similar characteristics to those based on the silica percentage, which are slightly different from those based on the $100 \mathrm{MgO} /$ Total $\mathrm{FeO}+\mathrm{MgO}+\mathrm{Alk}$ ratio. In any case all the frequency distribution curves for the lavas of volcanoes which have ejected lavas in historic times, show two principal peaks, which correspond to the peaks of frequency distribution of the volcanoes (Fig. 2b). This is a distinct fact to be noticed by petrologist as well as volcanologist.

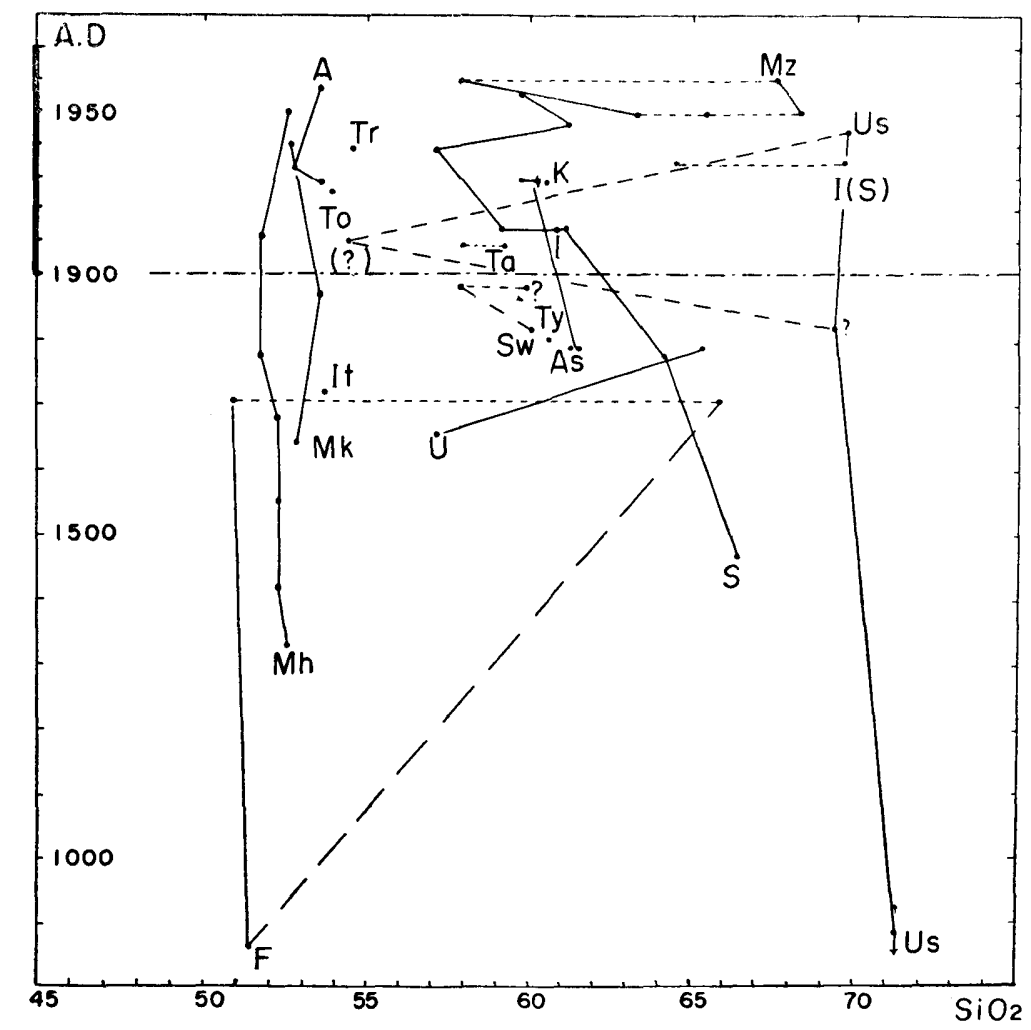

Fig. 4. Abbr. A Aso, As Asama, F Fuji (or Huzi), I Iwozima, Voic. Is, I (s) Iwo-zima, Satunan, It Iwate, K Komaga-dake, Hokkaido, Mh Mihara, Osima, Mk Miyakezima, Mz Myozin-syo, S Sakura-zima(Sakurajima), Sw Suwanose-zima, Ta Tarumai, To Tokati-dake, Tr Tori-sima, Izu, Ty Tyokai, U Unzen, Us Usu. 


\section{The variation trend of chemical composition of lavas throughout historic times}

a. The variation of $\mathrm{SiO}_{2}, \mathrm{MgO} /$ Total $\mathrm{FeO}+\mathrm{MgO}+\mathrm{Alk}$ and $\mathrm{Alk} /$ Total

$$
\mathrm{FeO}+\mathrm{MgO}+\mathrm{Alk}
$$

On arranging the $\mathrm{SiO}_{2}$ percentages and the $100 \mathrm{MgO} / \mathrm{Total} \mathrm{FeO}+\mathrm{MgO}+\mathrm{Alk}$ and $100 \mathrm{Alk} / \mathrm{Total} \mathrm{FeO}+\mathrm{MgO}+\mathrm{Alk}$ ratios according to the eruption period, it becomes manifest that (1) the silica content of the lavas have increased during the last period of the growth of each volcano (Fig. 4), with exception of the last products of Miyake-zima and Asama which more or less decreased in the silica; (2) The ratio $\mathrm{MgO}$ : (Total $\mathrm{FeO}+$ Alkalies) of the last products of all volcanoes with exception of Miyake-zima have decreased (Fig. 5); and (3) The ratio Alkalies: (Total FeO+MgO)

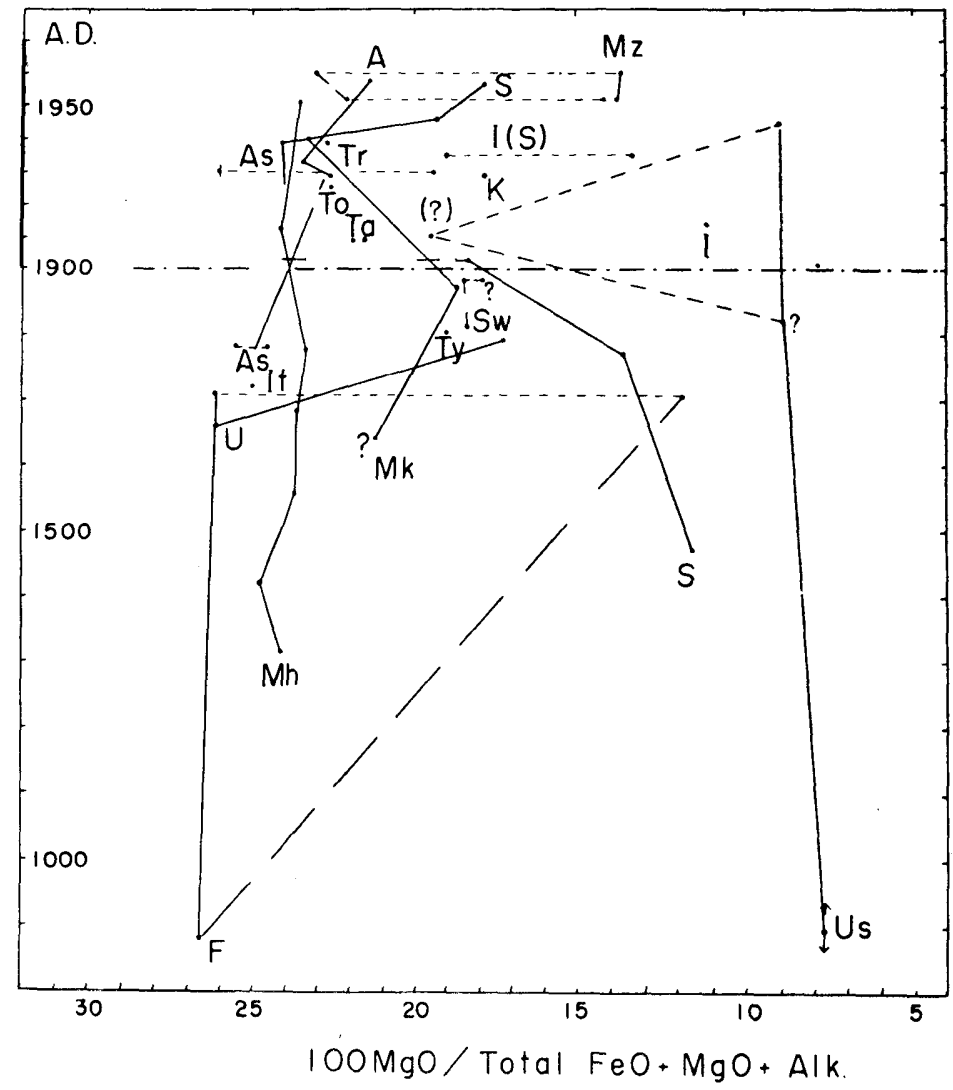

Fig. 5. Abbr. refer to Fig. 4.

of the last product of all volcanoes with exception of Miyake-zima, Asama and Suwanose-zima have increased (Fig. 6).

b. Sequence in the triangular Total $\mathrm{FeO}-\mathrm{MgO}-\mathrm{Alk}$ diagram

Most of the volcanoes except Miyake-zima have increased more or less in Total 
$\mathrm{FeO}$ at the last eruption period. Some of them have decreased in Alkalies, i.e. Asama, Mihara-yama and Suwanose-zima, and some of them have increased in Alkalies i.e. Sakura-zima and Unzen (Fig. 7).

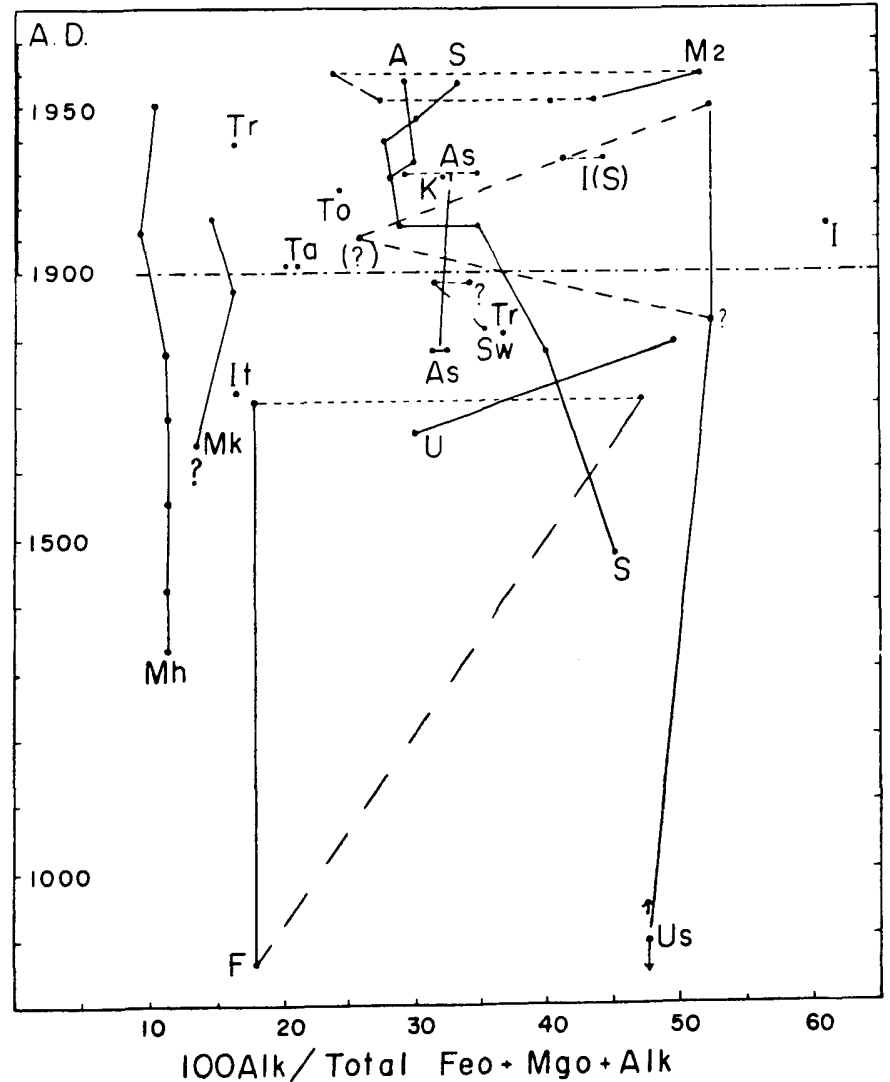

Fig. 6. Abbr. refer to Fig. 4.

Consequently the newer lavas occupy an elongated area perpendicular to the Total $\mathrm{FeO}-\mathrm{MgO}$ ridge ranging from a certain point near the Total $\mathrm{FeO}-\mathrm{MgO}$ ridge to a certain point near the Alkali apex, compared with the older ones (Fig. 8).

c. Normative feldspar

Description is not given here. See Fig. 7.

\section{Comparison of the lavas of historic times and those of prehistoric times in the ratio Total $\mathrm{FeO}: \mathrm{MgO}:$ Alkalies}

The lavas of historic times are plotted on the triangular diagram for the ratio Total $\mathrm{FeO}: \mathrm{MgO}$ : Alkalies, along with those of prehistoric times (Fig. 9). A glance at the diagram show the relation of the lavas of historic times to those of prehistoric times, which are classified into seven types as follows (1-7 of Table 4 \&Fig. 10): 

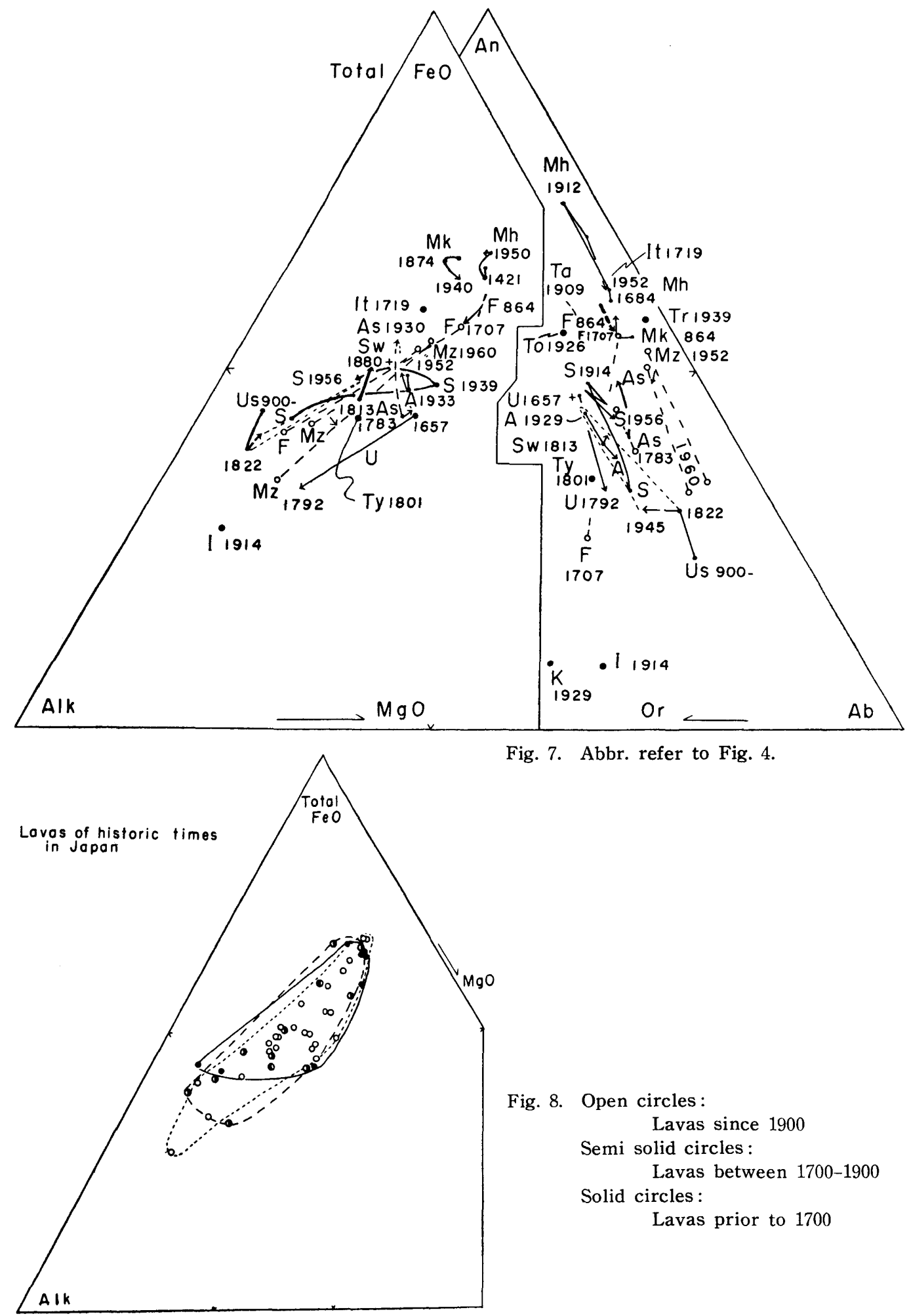

Fig. 7. Abbr. refer to Fig. 4.

Fig. 8. Open circles :

Lavas since 1900

Semi solid circles :

Lavas between 1700-1900

Solid circles :

Lavas prior to 1700 


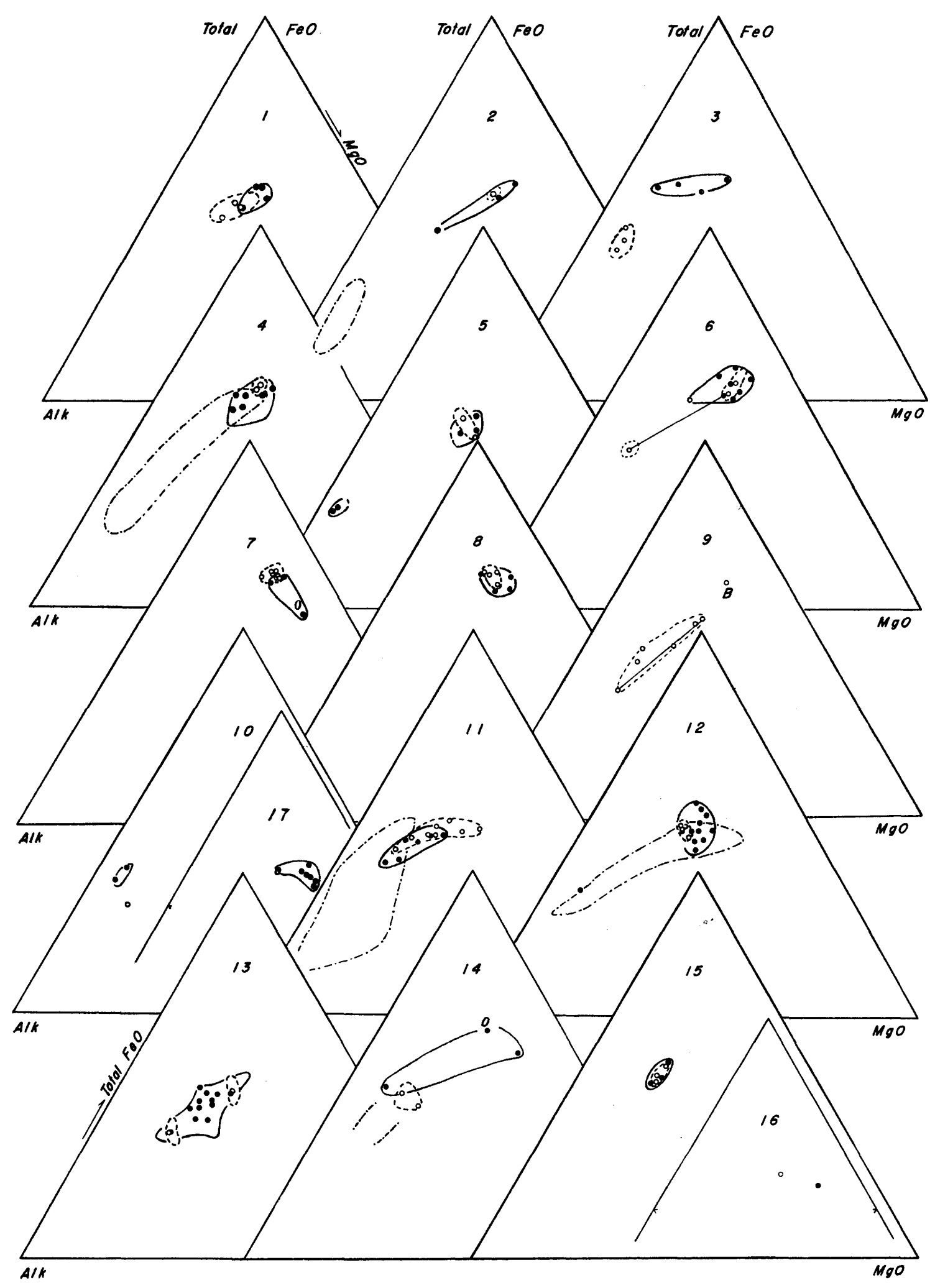

Fig. 9. Triangular diagram showing the ratio Total $\mathrm{FeO}: \mathrm{MgO}$ : Alk of lavas of Japanese vol. canoes, the lavas of historic times being enclosed by broken lines, and the lavas of prehistoric times enclosed by unbroken lines. Chain lines show the welded tuffs and lavas of the older volcanoes constructing the base of active volcanoes.

1 Komaga-dake, Hokkaido, 2 Tokati-dake, 3 Usu, 4 Tarumai, 5 Asama, 6 Huzi (Fuji)

7 Mihara-yama, Ôsima, 8 Miyake-zima, 9 Myozin-syo, 10 Iwo-zima, Volc. Is.,

11 Sakura-zima (Sakura-jima), 12 Aso, 13 Unzen, 14 Iwo-zima, Satunan, 15 Suwanose,

16 Tori-siam, Izu, 17 Iwate. 
Table 4. Relation between the lavas of historic times and those of prehistoric times in the ratio Total $\mathrm{FeO}: \mathrm{MgO}:$ Alkalies

A Lavas of historic times increase in Total $\mathrm{FeO}$ and/or Alkalies, compared with the lavas of prehistoric times.

Type 1 Basic group

Mihara-yama, Ôsima; Miyake-zima (-Type 6); Torisima, Izu; Iwate

Type 2 Intermediate group Komaga-dake, Hokkaido; Aso (excluding "Totinoki lava"); Iwo.zima (Satunan) (-Type 4)

Type 3 Acid group Usu

B Lavas of historic times decrease in Total $\mathrm{FeO}$, compared with the lavas of prehistoric times which rich in Total $\mathrm{FeO}$ and Alkalies.

Type 4 Iwo-zima (Volc. Ids.); Iwo-zima (Satunan) (--Type 2)

C Lavas of historic times are separated into two groups, basic and acid

Type 5 Myozin-syo; Huzi; Unzen

D Almost unchanged through historic and prehistoric times

Type 6

Suwanose-zima; Tokati-dake (-Type 7); Miyake-zima (-Type 1)

E Reverse of A

Type 7 Reverse of Type 2. Sakura-zima; Tarumai; Asama

Type 8 Reverse of Type 1

Type 9 Reverse of Type 3

Type 10 Reverse of Type 4
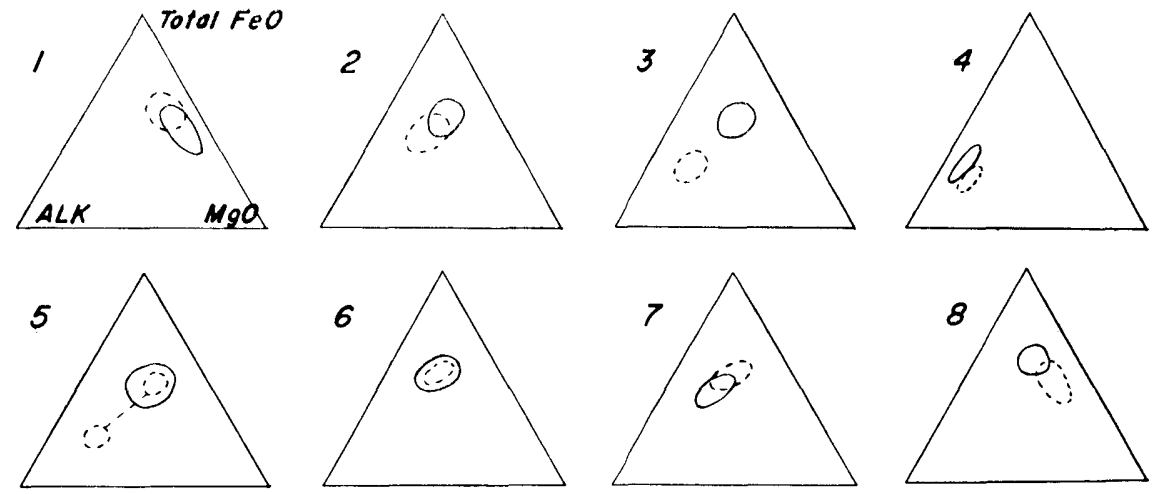

Fig. 10. Types of variation of lavas of historic (broken lines) and prehistoric (unbroken lines) times on the triangular Total FeO-MgO-Alkalies diagram. Nos. refer to Table 4 .

More detailed descriptions on the relations between the eruption type and the lava sequence in the Total $\mathrm{FeO}-\mathrm{MgO}-\mathrm{Alk}$ diagram will be given in another paper. 


\section{Appendix : Consideration from the petro-volcanological standpoint Example}

\section{Sakura-zima}

The Sakura-zima volcano (Lat. $31^{\circ} 35^{\prime} \mathrm{N}$, Long. $130^{\circ} 39^{\prime} \mathrm{E}$ ) is one of the most frequently erupted volcanoes in Japan. The eruptions of 1475-76, 1779, 1914 and 1946 flowed out lavas from the craters in the flank and foot of the volcano. The 1939 and 1956-present eruptions were also comparatively violent with emission of bombs. The acidity or $100 \mathrm{Alk} / \mathrm{Total} \mathrm{FeO}+\mathrm{MgO}+\mathrm{Alk}$ of the products has decreased successively throughout historic times until 1939, and then began to increase through the present summit eruption, as shown in Figs. 11. The 1946 lava has the less contaminated character. Concerning the eruptions of historic times, it is noticed that (1) the centres of eruptions in the flank have moved upwards successively throughout historic times, (2) the time intervals between the distinctive eruptions have decreased successively throughout historic times and (3) the depression of the ground caused by the eruption occurred in the Aira caldera and in its surrounding area, the main centre of subsidence agreeing with the form of the Aira caldera and the Sakura-zima volcano being only a subordinate centre. Considering these facts just mentioned and the relationship between the capacity of magma chamber, the temperature decrease, the differentiation degree, the trend of fractionation of magma, the length of dormant period prior to eruption and the amount of lavas effused by the eruption, I assume (a) the existence of two magma chambers, one (1) of which is situated at a deep place (about $10 \mathrm{~km}$ ) under the Aira caldera and larger than another one (2) which is situated at comparatively shallow place beneath the Sakura-zima volcano, and (b) the upwards moving of the chamber (2) through historic times. The capacity of the chamber (2) (about $1000 \mathrm{~m}$ in radius) has hardly varied through the historic times. It, however, may have decreased in capacity since the 1939 eruption. Such petrological extension of studies should be available for the consideration of possible eruption in the future also.

Table 5

\begin{tabular}{|c|c|c|c|c|}
\hline $\begin{array}{c}\text { Distinctive eruption } \\
\text { (A.D.) }\end{array}$ & & $\begin{array}{l}\text { roducts } \\
\left(\mathrm{SiO}_{2}\right)\end{array}$ & $\begin{array}{l}\text { Centre of eruption } \\
\text { (Altitude in m.) }\end{array}$ & $\underset{\text { (years) }}{\text { Time interval }}$ \\
\hline \multicolumn{5}{|l|}{766} \\
\hline $\begin{array}{l}1471- \\
1476\end{array}$ & Lava & 66.35 (av.) & 180 -Submarine & 705 \\
\hline 1779 & Lava & 64.13 (av.) & 700-Submarine & 303 \\
\hline 1914 & Lava & $61.04 \rightarrow 59.01$ & $570-200$ & 135 \\
\hline 1939 & Bomb & 57.11 (av.) & 750 & \multirow{2}{*}{$\begin{array}{ll}25 & 32 \\
7 & \end{array}$} \\
\hline 1946 & Lava & 61.25 (av.) & 800 & \\
\hline $1956-$ & Bomb & 59.63 & 1060 (Summit) & 19 \\
\hline
\end{tabular}




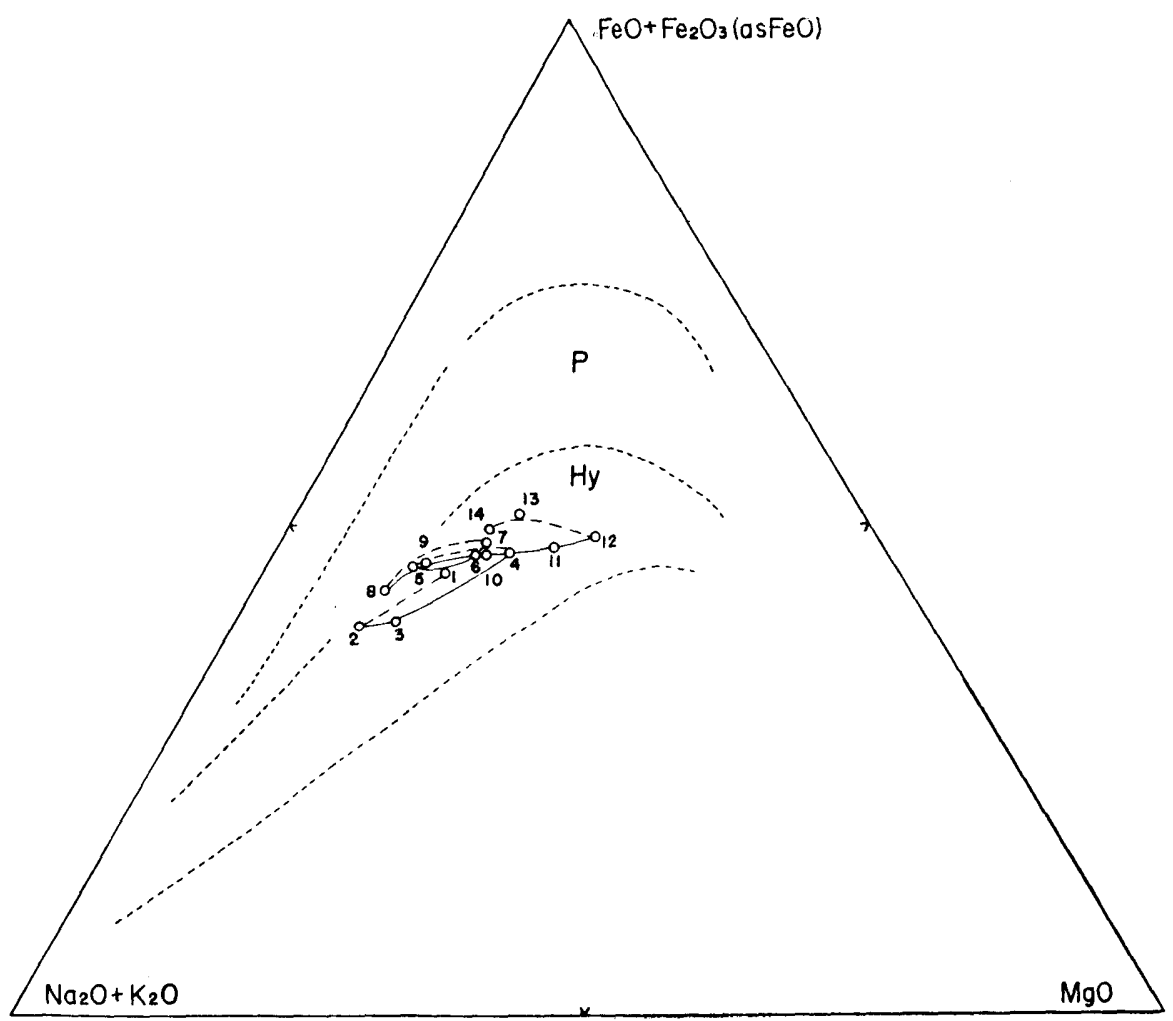

Fig. 11. Showing the fractionation trend and the sequence of effusions of Sakura-zima. No.

1 Kita-dake lava (Augite-bearing hypersthene andesite)

2 Kita-dake Scoria (Do.)

3 Kita-dake, parasitic lava (Do.)

4 Minami-dake lava I [(Olivine- and) augite-bearing hypersthene andesite]

5 Minami-dake lava II and agglomerate containing Naka-dake agglomerate (Augite-hypersthene-andesite)

6 Lava of unknown period

7 Nabeyama (parasitic) ejecta (Two-pyroxene andesite)

8 Bunmei lava $(1471,1476)$ (Augite-hypersthene andesite)

9 An-ei lava (1779) [(Olivine-bearing) augite-hypersthene andesite]

10 Taisho lava I (1914) (Olivine-bearing augite-hypersthene andesite)

11 Taisho lava II (1914) (Do.)

12 Showa bomb I (1939) (Two pyroxene andesite)

13 Showa lava (1946) (Do.)

14 Showa bomb II (1956) (Do.)

1-12 Taneda, S. (1952, contributed by K. Yamaguchi): guide book of Sakura-jima, Kyushu Univ. (in Japanese)

13 Morimoto, R. (1948): Geological and petrological notes on the eruption of Sakurajima in 1946. Part II. Bull. Earthq. Res. Inst., 26, 37-40.

14 Taneda, S. \& Morita, J. (1958): New bomb of the Sakura-jima volcano. Jour. Jap. As. Petr. Min. Ec'Geol., 42, 202-203 (in Japanese). 


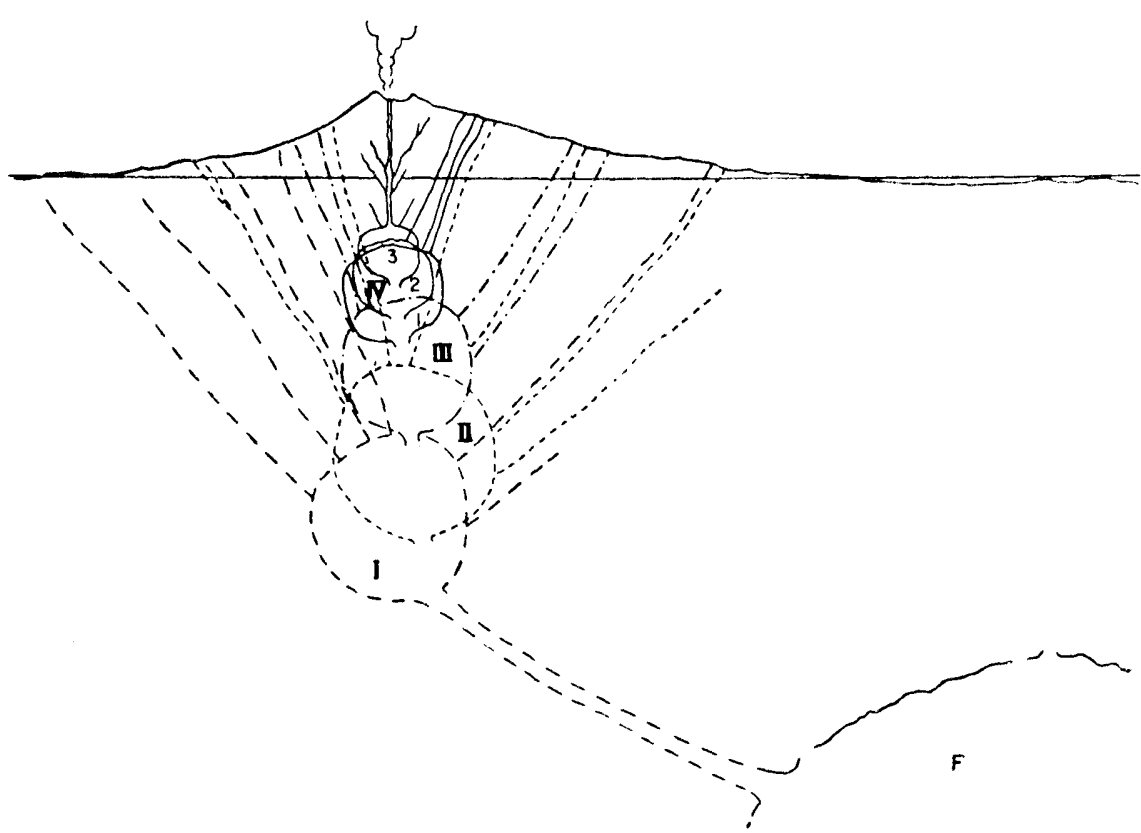

Fig. 12. Schematic sketch showing the upward moving of magna chamber 2 .

I Magma chamber 2 for the Bunmei eruption (1946-76)
II
III

\section{References}

Chemical analyses refer to Table 1.

Ishikawa, T. \& Katsui, Y. (1959): Some considerations on the Relation between the chemical character and geographical position of the volcanic zones in Japan. J. Fac. Sci., Hokkaido Univ., Ser. 4, Geol. and Miner., 10, 163-182.

Taneda, S. (1951): Studies on the volcanoes in Japan-the chemical compositions of the lava (1) (in Japanese). Rep. Fac. Sci., Kyushu Univ., Geology, 3, 55-75.

Taneda, S. (1952): New average chemical compositions of Japanese effusive rocks. J. Geol. Soc. Japan, 58, 517-21.

Taneda, S. (1961): Moving of the magma chamber of the Sakura-jima volcano. J. Geol. Soc. Japan, 67, 593-603.

Taneda, S. (1961): Petrochemical study on the volcanic rocks of Indonesia (in Japanese with English abstract). Sci. Rep. Fac. Sci. Kyushu Univ., (Geol.), 5, 181-195. 